\title{
EVALUATION OF SOME PRODUCTIVE TRAITS IN BREEDS LARGE WHITE AND DUROC
}

\author{
Fidel Gjurgji $^{1}$, Arjan Shumeli ${ }^{1}$, Luan Hajno ${ }^{2}$, Vilson Bozgo ${ }^{1}$ \\ ${ }^{1}$ Departament of Animal Production at Agricultural University of Tirana, Albania \\ ${ }^{2}$ Agriculture Technology Transfer Center, Fushe-Kruje, Albania \\ fidelgj@yahoo.com
}

\begin{abstract}
For the purposes of the current study 10 sows belonging to two populations including the breeds Large White and Duroc have been respectively analyzed. The traits looked at closely include born alive per litter, the litter size and the average daily gain. In the case of the Large White the difference measured in days between the two parities was roughly 148 days and litters/sows/year 2.4, while in the Duroc breed it is roughly 163 days or 15 days more, and litter/sows/year 2.2. The litter size was 11.8 piglets per litter per the Large White breed against the 9.7 that the Duroc breed yields or 2.1 piglets more. This difference or change is easily noticed during the lactation period until the $28^{\text {th }}$ day. The amount of milk yielded from the Large White sows from the parity number 1 is $67.2 \mathrm{~kg}$, while that from the Duroc sows is $55 \mathrm{~kg}$. The litter size of the Large White breed from the first parity to the second grows by 0.8 and from the second parity to the third by 1.4 piglets. The study reveals that the average weight of piglets at birth is 1460 gram for the Large White and 1320 gram for the Duroc respectively. This difference is seen during the lactation period until the 28-day. The average weight of piglets for the Large White reaches $7.3 \mathrm{~kg}$, while for the Duroc is $6.9 \mathrm{~kg}$. From this age onward the Duroc displays advantages for this indicator when compared with the Large White. The study also indicates that the Large White is known for a litter of large size at birth and a better growth rate until the age of 28 days. The Duroc breed shows a high growth rate and this trait is passed down to the next-generation. The two populations indicate variability for each distinct trait, which creates a possibility for a better selection.
\end{abstract}

Key words: breed; piglets; litter size; litters/sows/year; lactation; average daily gain

\section{ПРОЦЕНА НА НЕКОИ ПРОИЗВОДНИ КАРАКТЕРИСТИКИ НА РАСИТЕ ГОЛЕМА БЕЛА И ДУРОК}

Во оваа студија се анализирани 10 назимки од две популации, голема бела и дурок. Карактеристиките кои се анализирани вклучуваат живородени по легло, големина на легло и просечен дневен прираст. Во случајот на големата бела, разликата измерена во денови помеѓу двете пресметки беше околу 148 дена и добиени се 2,4 легла/маторица годишно, додека кај расата дурок беше околу 163 дена, односно 15 дена повеќе и добиени се 2,2 легла/маторица годишно. Големината на леглото кај големата бела беше 11,8 прасиња по легло, во споредба со 9,7 кај расата дурок, т.е. за 2,1 прасе повеќе. Оваа разлика или промена е лесно забележлива за време на лактациониот период сѐ до 28-иот ден. Количината на млекото кај маториците голема бела при првото легло е $67,2 \mathrm{~kg}$, додека кај маториците дурок е $55 \mathrm{~kg}$. Големината на леглото кај големата бела од првото до второто легло расте за 0,8 , а од второто до третото легло за 1,4 прасиња. Студијава покажува дека просечната маса на прасињата при раѓање е $1460 \mathrm{~g}$ за голема бела и $1320 \mathrm{~g}$ за дурок. Оваа разлика е видлива за време на лактациониот период сѐ до 28-иот ден: просечната маса на прасињата кај големата бела достигнува $7,3 \mathrm{~kg}$, додека кај дурок $6,9 \mathrm{~kg}$. Меѓууоа, од оваа возраст па понатаму дурокот покажува предности за овој показател во споредба со големата бела. Студијата исто така покажува дека големата бела е позната по легла со голема маса при раѓање и подобар процент на прираст сѐ до возраст од 28 дена. Расата дурок покажува висок процент на прираст и оваа карактеристика се пренесува на следната генерација. Двете популации покажуваат различност за секое одделно својство, што создава можност за подобра селекција.

Клучни зборови: раса; прасиња; големина на легло; легла/маторица/година; лактација; просечен дневен прираст 


\section{MATERIAL AND METHOD}

The study was conducted under the conditions of a positive economic growth in Lezha, Albania. The feeding and the micro-climate requirements are in a full line with the technological requirements for such a growth. For purposes of the study 10 sows of two populations have been taken: Large White and Duroc, respectively. As a basis of the study regarding the size of litter the second birth has been taken, and aside from this, the progress is reported on the $2^{\text {nd }}$ and $3^{\text {rd }}$ births.

While for purposes of studying the rate of growth of their offspring some 20 piglets have been taken based on the respective breeds from the age of 65 days up to 130 days and 220 days.

In order to make certain that work proceeded smoothly from here the following organization problems were attended to: of $28^{\text {th }}$ day;

- identification (record) of piglets at the age

- mating animals taking care to avert the blood compatibility by utilizing rotation; each sow;

- registration of the copulations and births for

- registration of the reproduction indicators for each sow by means of cards;

- registration of weight and dynamics of growth for each piglets based on the age indicator:
a) at birth
b) into the $28^{\text {th }}$ day
c) into the $65^{\text {th }}$ day
d) into the $130^{\text {th }}$ day
e) into the $220^{\text {th }}$ day
f) size of litter at birth.

The daily gain in weight was calculated based on the formula:

in which:

$$
\frac{Z-V}{A_{f}-A_{b}}
$$

$Z$ - live weight at the end of the period,

$V$ - live weight at the start of the period,

$A_{f}$ - age at the end of the period,

$A_{b}$ - age at the start of the period.

Other set of indicators recorded included:
a) weight and litter size at birth
b) weight and litter size in the weaning
c) weight of litte into the $65^{\text {th }}$ day
d) weight of litterr size into the $220^{\text {th }}$ day
e) daily weight for each period of time.

The purpose of the study is get to know the genetic and reproductive capacity of these breeds, the size of litter and their weight, the growth rate of their offspring until the point of sale. All of these combined together will bring out to the fore the abilities of these breeds in the increase of pig meat quality and the effectiveness of rearing them.

\section{The breeding conditions}

During the first month of pregnancy the adequate amount of feed was used for the sows in order to supply the requirements for maintenance and to restore the sow's body condition and to build up reserves fat. In the first stage of pregnancy $2.1-2.3 \mathrm{~kg} / \mathrm{feed} / \mathrm{sow}$ per day were used. During the last month a large proportion of the feeds were used for fetal development, the growth of the udder.

In the last weeks when the sows transfer to the farrowing unit the feed changes to lactation feed.

For all sows the feed ration is given twice a day. The water is taken through a drinking instrument depending on the need. In the case of piglets during lactation the only food used is colostrums used in the first days along with ordinary milk. During this period the enzymatic system of digestion is capable of utilizing only milk that is taken in the form of sows. The supplementary feed depends much on the requirements of piglets and the extent of meeting it through milk in sows. When the nutrients obtained through the use of milk to be inadequate then that's when supplementary feed comes along, the daily amount of which for each piglet comes from the difference that is not provided (requirement - the amount of milk yielded from sows).

The supplementary feed (pre-starter) is given in the middle of the second week, since during this period we witness an increase in the difference between the requirements of the piglets in energy and proteins and provision of such nutrients through milk. Precisely, his difference will have to be supply through feed. This allows the pigs to become accustomed to plant-related feed and to avoid any shock resulting from the huge amount of feed or when they are weaned. The pre-starter contains $13.5 \mathrm{MJ} \mathrm{EM} / \mathrm{kg}$ and $21 \% \mathrm{CP}$, at a time when the most developed digestion tract of the weaned piglets tolerates a lower concentration of nutrients in the pre-starter II (12.5 MJ EM/kg and $17 \% \mathrm{CP})$. 
The studies have shown that in order to promote development of the enzyme system during the second week the piglets should take the supplementary feed (pre-starter) and during the first day of the sixth week, piglets are given pre-starter and starter feed.

\section{INTERPRETATION OF DATA}

\section{a) Productivity}

- One of the purposes related to rearing sows is to get as many litters out of it as possible. In order to obtain meat at low cost the productive abilities of sows have to be rationally and effectively used.

- In the Large White the difference in days between the two parities is roughly 148 days, while in the Duroc breed is roughly 163 days or 15 days more.

- With regard to the economic efficiency of breeding the species, the number of births for each sow per year is very important.

- In the case of the Large White the difference measured in days between the two parities was roughly 148 days and litters/sows/year 2.4, while in the Duroc breed it is roughly
163 days, or 15 days more, and litter/sows/ year 2.2.

- From the data it turns out that the Large White has a higher productivity than the Duroc breed.

\section{b) Size of litter}

In calculating the litter size, the second and third litters have been looked at for all of the sows.

- The comparison of data reveals that the LW has a larger litter size than the Duroc breed.

- The Large White provides on average of 11.8 piglets per litter as opposed to the Duroc with 9.7 piglets, or some 2.1 piglets more.

- This difference between the two continues even into the $28^{\text {th }}$ day of lactation when weaning occurs.

- Yet another set of data of importance has to do with the amount of milk produced. The more milk the sow has, the quicker the piglets grow up and the more weight they gain when they are weaned. The amount of milk in the case of LW is on average $67.2 \mathrm{~kg}$, while in the case of the Duroc is $55 \mathrm{~kg}$, or $12 \mathrm{~kg}$ less.

Table 1

Several productive data in the second litter, at birth and 28 days for the Large White

\begin{tabular}{|c|c|c|c|c|c|c|c|c|}
\hline \multirow{2}{*}{$\begin{array}{c}\text { Number } \\
\text { of sow } \\
\text { card }\end{array}$} & \multicolumn{3}{|c|}{ At birth } & \multicolumn{3}{|c|}{ Into the $28^{\text {th }}$ day } & \multicolumn{2}{|c|}{ Mortality } \\
\hline & $\begin{array}{l}\text { Number of } \\
\text { piglets BA }\end{array}$ & $\begin{array}{l}\text { Litter-live } \\
\text { weight kg }\end{array}$ & $\begin{array}{l}\text { Piglets-live } \\
\text { weight kg }\end{array}$ & $\begin{array}{l}\text { Number of } \\
\text { piglets }\end{array}$ & $\begin{array}{l}\text { Litter-live } \\
\text { weight kg }\end{array}$ & $\begin{array}{l}\text { Piglets-live } \\
\text { weight kg }\end{array}$ & $\begin{array}{l}\text { Number of } \\
\text { piglets }\end{array}$ & $\%$ \\
\hline 053 & 10 & 12.5 & 1.250 & 8 & 41.1 & 5.14 & 2 & 20 \\
\hline 812 & 10 & 12.2 & 1.220 & 10 & 56.5 & 5.65 & - & - \\
\hline 187 & 14 & 17.0 & 1.214 & 12 & 79.5 & 6.63 & 2 & 14.2 \\
\hline 130 & 10 & 13.0 & 1.300 & 9 & 67.6 & 7.51 & 1 & 10 \\
\hline 927 & 11 & 12.0 & 1.090 & 10 & 63.5 & 6.35 & 1 & 9 \\
\hline 368 & 11 & 12.1 & 1.100 & 10 & 70.2 & 7.02 & 1 & 9 \\
\hline 572 & 11 & 14.0 & 1.270 & 11 & 73.1 & 6.64 & - & - \\
\hline 091 & 15 & 15.0 & 1.000 & 13 & 63.1 & 4.85 & 2 & 13.3 \\
\hline 360 & 15 & 17.2 & 1.146 & 12 & 85.0 & 7.08 & 3 & 20 \\
\hline 614 & 11 & 13.0 & 1.181 & 9 & 78.5 & 8.72 & 2 & 18 \\
\hline
\end{tabular}


Table 2

Several productive data in the second litter, at birth and 28 days for the Duroc

\begin{tabular}{l|ccc|ccc|cc}
\hline \multirow{2}{*}{$\begin{array}{l}\text { Number of } \\
\text { sow card }\end{array}$} & \multicolumn{4}{|c|}{ At birth } & \multicolumn{3}{|c|}{ Into the $28^{\text {th }}$ day } & \multicolumn{2}{|c}{ Mortality } \\
\cline { 2 - 9 } & $\begin{array}{c}\text { Number of } \\
\text { piglets BA }\end{array}$ & $\begin{array}{c}\text { Litter-live } \\
\text { weight kg. }\end{array}$ & $\begin{array}{c}\text { Piglets-live } \\
\text { weight kg }\end{array}$ & $\begin{array}{c}\text { Number of } \\
\text { piglets }\end{array}$ & $\begin{array}{c}\text { Litter-live } \\
\text { weight kg }\end{array}$ & $\begin{array}{c}\text { Piglets-live } \\
\text { weight kg }\end{array}$ & $\begin{array}{c}\text { Number of } \\
\text { piglets }\end{array}$ & $\%$ \\
\hline 476 & 9 & 11.1 & 1.230 & 8 & 49.6 & 6.2 & 1 & 11.1 \\
086 & 7 & 9.1 & 1.300 & 7 & 58.1 & 8.3 & - & - \\
581 & 9 & 11.4 & 1.270 & 9 & 64.1 & 7.2 & - & - \\
687 & 12 & 14.3 & 1.190 & 12 & 76.6 & 6.3 & - & - \\
811 & 12 & 14.2 & 1.180 & 9 & 61.4 & 6.8 & 3 & 25 \\
877 & 7 & 11.3 & 1.620 & 7 & 43.9 & 6.2 & - & - \\
656 & 9 & 11.3 & 1.250 & 8 & 53.9 & 6.7 & 1 & 11.1 \\
660 & 11 & 14.0 & 1.270 & 8 & 39.8 & 4.9 & 3 & 27.3 \\
164 & 11 & 14.6 & 1.330 & 8 & 48.2 & 6.0 & 3 & 27.3 \\
180 & 10 & 12.0 & 1.200 & 9 & 60.09 & 6.7 & 1 & 10 \\
\hline
\end{tabular}

T a b l e 3

The litter size for the two breeds of the $B W$ and the Duroc in three successive parities

\begin{tabular}{ccc|ccc}
\hline \hline \multicolumn{3}{c|}{ Large White } & \multicolumn{3}{c}{ Duroc } \\
$1^{\text {st }}$ litter & $2^{\text {nd }}$ litter & $3^{\text {rd }} l i t t e r$ & $1^{\text {st }} l i t t e r$ & $2^{\text {nd }} l i t t e r$ & $3^{\text {rd }} l i t t e r$ \\
\hline 9.8 & 11.8 & 12.6 & 8.9 & 9.7 & 11.1 \\
\hline \hline
\end{tabular}

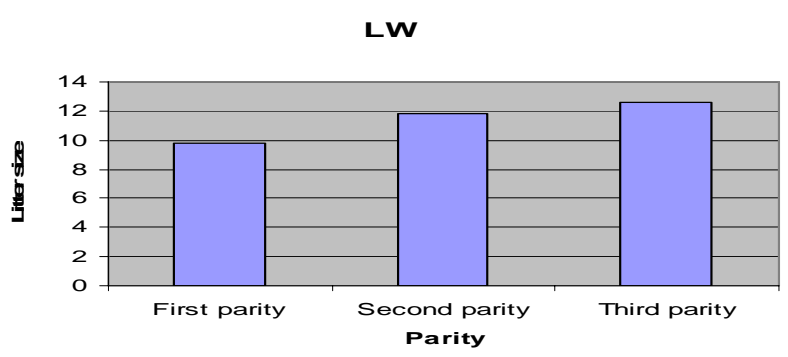

Graph 1. Progress of the litter size for three successive parities in the LW

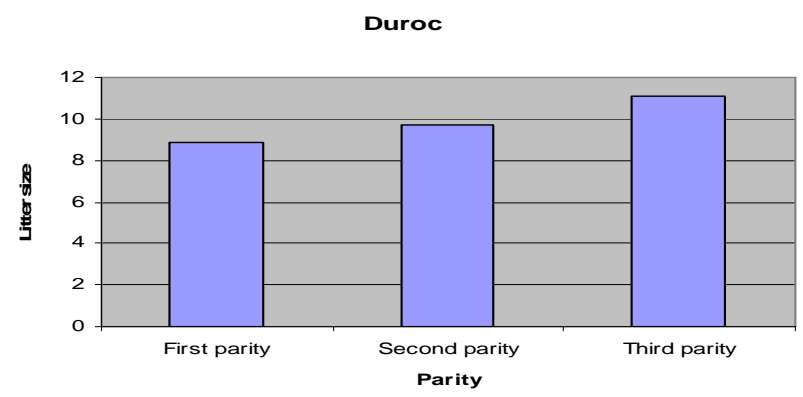

Graph 2. Progress of the litter size in three successive Parities in the Duroc

\section{c) Growth rate}

The growth rate in pigs reared for meat is a significant indicator in evaluating pigs. This might be attributed to two essential moments: the improvement of the breed level and the growth effectiveness. The growth rate is expressed in the number of days that is taken in gaining an optimal body weight of $100 \mathrm{~kg}$. This is stipulated by the average daily gain.

From the data it turns out that at birth the weight of piglets of the Duroc breed is $1460 \mathrm{~g}$ in relation to the weight of $1326 \mathrm{~g}$ of the $\mathrm{LW}$, or some $134 \mathrm{~g}$ more. This is an important indicator in the later development. At the age of 28 days these indicators vary significantly. The sow (LW) because of the high quality milk it produces is capable of rearing piglets much better with an average weight growth of $7.3 \mathrm{~kg}$ against $6.9 \mathrm{~kg}$ of the Duroc, or $0.4 \mathrm{~kg}$ more.

At the age of 65-70 days, the Duroc breed shows advantages against the BW. Hence at the age of 65-70 days the body weight of the Duroc is 23.8 against the $19.2 \mathrm{~kg}$ of the $\mathrm{BW}$.

The same tendency is seen at the age of 130 days, where the Duroc shows an advantage over the BW of some $13 \mathrm{~kg}$.

As a result of this rapid growth, the Duroc breed gains a weight of $100 \mathrm{~kg}$ in 13 days period to the BW breed, even though it has $40 \mathrm{~kg}$ less feed per sow. 
Table 4

\section{Relationship between live weight and age in both $L W$ and Duroc}

\begin{tabular}{|c|c|c|c|c|c|}
\hline Breeds & $\begin{array}{c}\text { Birth } \\
\text { weight }\end{array}$ & $\begin{array}{l}\text { Weight at } \\
28 \text { days }\end{array}$ & $\begin{array}{c}\text { Weight at } \\
65 \text { days }\end{array}$ & $\begin{array}{l}\text { Weight at } \\
130 \text { days }\end{array}$ & $\begin{array}{l}\text { Weight at } \\
220 \text { days }\end{array}$ \\
\hline & $\mathrm{kg}$ & $\mathrm{kg}$ g/day & $\mathrm{kg} \quad \mathrm{g} / \mathrm{day}$ & $\mathrm{kg} \mathrm{g} /$ day & $\mathrm{kg} \mathrm{g} /$ day \\
\hline LW & 1.320 & $\begin{array}{ll}7.3 & 213\end{array}$ & 19.2320 & $45.2 \quad 400$ & $95 \quad 550$ \\
\hline DUROC & 1.466 & $6.9 \quad 194$ & $23.8 \quad 345$ & $58.9 \quad 540$ & $110 \quad 570$ \\
\hline
\end{tabular}

\section{LW and Duroc breeds}

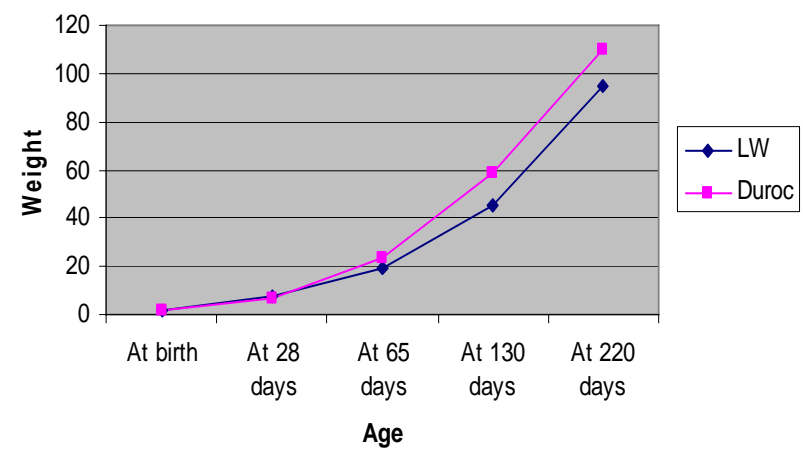

Graph 3. Progress of live weight $(\mathrm{kg})$ in relation to age (days) in LW and Duroc. (compared)

\section{LW and Duroc breeds}

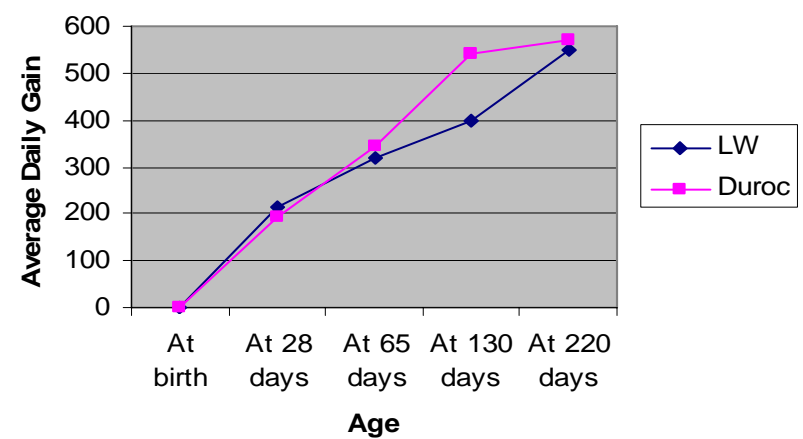

Graph 4. Progress of average daily gain in relation to age (days) in LW and Duroc (compared)

From the above it's easy to point to the better qualities that the Duroc breed shows a high growth rate and this trait is passed down to the nextgeneration. Thus this breed has much more advantages when used as the father breed in the crossbreeds.

\section{CONCLUSIONS}

From the study one can safely conclude that: The two breeds have high genetic and productive abilities. The LW is set apart for a larger litter size and a better growth until the age of 28 days, when piglets are being fed with the milk of the sow. For above reasons it's recommended that it acts as a mother breed in cross-breeds. The Duroc breeds exhibit features that are common to the standards of the breed itself. The Duroc breed has a high growth rate, a feature which is easily inherited in the offspring. For the above reasons it's recommended that it acts as a father breed in the crossbreeds. The two populations indicate variability for each distinct trait, which creates a possibility for a better selection.

Just because of this variability, there is space for much further research in the field.

\section{REFERENCES}

[1] Aherne, F. X., H. Miller, E. Clowes, L. Zak, (1995): Nutritional effects on sow reproduction. Proc. Minesota $\mathrm{Nu}$ trition Conference.

[2] Burlacu, G., M. Iliescu, P. Caramida (1993): Efficiency of food utilization by pregnant and lactating sows. 1 . The influence of diets with different concentration of energy on pregnancy and lactation. Arch. Tierenah, 33, 23-45.

[3] Cleveland, E. R., Johnson, R. K., Cunningham, P. J. (1988): Correlated response of carcass and reproductive traits to selection for rate of lean growth in swine. J. of Animal Sci. 66 (6): 1371-1377.

[4] Elsey, F. W. H. (1971): Nutrition and lactation in the sow. In: I.R. Faulkner (Ed.) Lactation, Butterworths, London, 393-411.

[5] Hovell, F. D., De. B., R. M.. MacPherson. R. M. J. Crofts, K. Pennie (1977): The effect of energy intake and mating weight on growth, carcass yield and litter size of female pigs. Anim. Prod. 30, 469 (Abs).

[6] Whittemore, C. T., A. Aumaitre, I Williams (1978): Growth of bodycomponents in young weaned pigs. Journal of Agricultural Science, 91, 681-692.

[7] Williams (1978): Growth of body components in yong weaned pigs. Journal of Agricultural Science, 91, 681692. 
